\title{
Development of Stable Mixed Microbiota for High Yield Power to Methane Conversion
}

\author{
Márk Szuhaj ${ }^{1}$, Roland Wirth ${ }^{1}$, Zoltán Bagi ${ }^{1}$, Gergely Maróti ${ }^{2} \mathbb{D}$, Gábor Rákhely ${ }^{1,3}{ }^{\mathbb{D}}$ and Kornél L. Kovács ${ }^{1,4, * \mathbb{D}}$ \\ 1 Department of Biotechnology, University of Szeged, 6726 Szeged, Hungary; szuhaj@bio.u-szeged.hu (M.S.); \\ wirth.roland@brc.hu (R.W.); bagi.zoltan@brc.hu (Z.B.); rakhely.gabor@brc.hu (G.R.) \\ 2 Institute of Plant Biology, Biological Research Centre, 6726 Szeged, Hungary; maroti.gergely@brc.hu \\ 3 Institute of Biophysics, Biological Research Centre, 6726, Szeged, Hungary \\ 4 Department of Oral Biology and Experimental Dentistry, University of Szeged, 6720 Szeged, Hungary \\ * Correspondence: kovacs.kornel@bio.u-szeged.hu
}

Citation: Szuhaj, M.; Wirth, R.; Bagi, Z.; Maróti, G.; Rákhely, G.; Kovács, K.L. Development of Stable Mixed Microbiota for High Yield Power to Methane Conversion. Energies 2021, 14, 7336. https://doi.org/10.3390/ en14217336

Academic Editor: Jaakko Puhakka

Received: 21 September 2021

Accepted: 30 October 2021

Published: 4 November 2021

Publisher's Note: MDPI stays neutral with regard to jurisdictional claims in published maps and institutional affiliations.

Copyright: () 2021 by the authors. Licensee MDPI, Basel, Switzerland. This article is an open access article distributed under the terms and conditions of the Creative Commons Attribution (CC BY) license (https:// creativecommons.org/licenses/by/ $4.0 /)$.

\begin{abstract}
The performance of a mixed microbial community was tested in lab-scale power-to-methane reactors at $55{ }^{\circ} \mathrm{C}$. The main aim was to uncover the responses of the community to starvation and stoichiometric $\mathrm{H}_{2} / \mathrm{CO}_{2}$ supply as the sole substrate. Fed-batch reactors were inoculated with the fermentation effluent of a thermophilic biogas plant. Various volumes of pure $\mathrm{H}_{2} / \mathrm{CO}_{2}$ gas mixtures were injected into the headspace daily and the process parameters were followed. Gas volumes and composition were measured by gas-chromatography, the headspace was replaced with $\mathrm{N}_{2}$ prior to the daily $\mathrm{H}_{2} / \mathrm{CO}_{2}$ injection. Total DNA samples, collected at the beginning and end (day 71), were analyzed by metagenome sequencing. Low levels of $\mathrm{H}_{2}$ triggered immediate $\mathrm{CH}_{4}$ evolution utilizing $\mathrm{CO}_{2} / \mathrm{HCO}_{3}{ }^{-}$dissolved in the fermentation effluent. Biomethanation continued when $\mathrm{H}_{2} / \mathrm{CO}_{2}$ was supplied. On the contrary, biomethane formation was inhibited at higher initial $\mathrm{H}_{2}$ doses and concomitant acetate formation indicated homoacetogenesis. Biomethane production started upon daily delivery of stoichiometric $\mathrm{H}_{2} / \mathrm{CO}_{2}$. The fed-batch operational mode allowed high $\mathrm{H}_{2}$ injection and consumption rates albeit intermittent operation conditions. Methane was enriched up to $95 \% \mathrm{CH}_{4}$ content and the $\mathrm{H}_{2}$ consumption rate attained a remarkable $1000 \mathrm{~mL} \cdot \mathrm{L}-1 \cdot \mathrm{d}^{-1}$. The microbial community spontaneously selected the genus Methanothermobacter in the enriched cultures.
\end{abstract}

Keywords: power-to-gas; thermophilic biogas; fed-batch reactor; Methanothermobacter; metagenome; starvation; $\mathrm{H}_{2}$ and $\mathrm{CO}_{2}$ conversion; methane; acetate

\section{Introduction}

The energy needs of civilized human lifestyle and the global population are increasing rapidly. The majority of this energy is provided currently from fossil energy carriers. Exploitation of fossil sources is associated with greenhouse gas (GHG) emission, which is the primary source of global climate change endangering the biosphere and overall quality of life on Earth. These are the driving forces for the increase of the contribution of renewable energy in the overall energy spectrum. Photovoltaics (PV), wind, hydro, and biomass are the major sources available [1,2]. The particularly rapid growth in energy production via PV and wind is much appreciated although the fluctuating nature of electricity generation using these forms of incoming solar energy presents additional challenges for the distribution and utilization systems [3,4]). Smart electricity grids and flexible storage technologies are being developed to balance the energy losses and grid imbalances due to the deranged production and utilization of electricity [5].

The mass-based energy content and carbon-free nature of hydrogen makes $\mathrm{H}_{2}$ an excellent energy storage medium. $\mathrm{H}_{2}$ can be produced in various ways [6], water electrolysis being the most commonly employed among them [7]. Conversion to a hydrogen economy [8-10] is an attractive scenario, which could help restore the rapidly deteriorating 
climate conditions. The primary hurdles to large scale $\mathrm{H}_{2}$ use include underdeveloped storage and transport technologies, which are still costly and energy demanding $[8,10]$.

Methane $\left(\mathrm{CH}_{4}\right)$ is also an excellent potential energy delivery material but it can contribute to GHG emission, due to its carbon content, unless generated via a renewable energy conversion process [11,12]. A significant advantage of $\mathrm{CH}_{4}$ as an energy carrier is the efficient and advanced storage and transport pipeline system developed for natural gas, the fossil and thus less environmentally friendly form of $\mathrm{CH}_{4}$ [13,14]. Biogas, a mixture of $\mathrm{CH}_{4}(60-70)$, carbon dioxide (30-40\%), and $1-2 \%$ of other gases [15], is generated during the anaerobic decomposition (AD) of biomass, a renewable form of stored solar energy continuously supplied on Earth via photosynthesis $[16,17]$. AD of biomass is carried out by a complex microbial community, biogas is formed in the last step of the multifarious biochemical process by methanogenic microbes. Based on their substrate preference, methanogens are classified in three groups, i.e., acetotrophic, hydrogenotrophic, and methylotrophic methanogens, all belonging in the phylum Euryarchaeota within the kingdom Archaea [18]. Hydrogenotrophic methanogens reduce carbon dioxide $\left(\mathrm{CO}_{2}\right)$ to $\mathrm{CH}_{4}$ when the appropriate reducing power, i.e., $\mathrm{H}_{2}$ or low redox potential electrons, is available. $\mathrm{H}_{2}$ can be obtained from water electrolysis powered by renewable electricity, closing the circular character of this energy conversion process, called Power-to-Methane (P2M) $[7,15,19,20]$. P2M is accomplished either within the biogas producing AD reactor, i.e., in situ P2M, or in a separate reactor vessel, i.e., ex situ P2M, or in a combination thereof $[15,19]$. The advantages and disadvantages of the various reactor arrangements have been discussed extensively [15,21-23]. Methanogens, the key players in the P2M process can be employed in sterile, pure cultures [24-27] or in a mixed anaerobic microbial community [13,28-34]. An inexpensive, readily available source of the anaerobic methanogen community is the fermentation effluent of the biogas reactor itself, which is enriched in methanogens during the course of P2M [28,35].

A lab-scale proof of concept is presented in this study, in which the fermentation residue of an industrial thermophilic $\mathrm{AD}$ reactor is used to catalyze the $\mathrm{P} 2 \mathrm{M}$ conversion of $\mathrm{H}_{2}$ and $\mathrm{CO}_{2}$ while the alterations of the microbial community under the selection pressure of the experimental conditions are established.

\section{Materials and Methods}

\subsection{Fermentation System}

The total volume of each batch reactor was $160 \mathrm{~mL}$ (Wheaton glass serum bottle, Z114014 Aldrich) and contained $40 \mathrm{~mL}$ fermentation effluent from the thermophilic industrial biogas plant Bátortrade Kft. Nyírbátor, Hungary. The main substrates at Bátortrade are animal waste $(39.1 \%)$, manure $(29.7 \%)$, agricultural waste $(18.9 \%)$, and ensilaged green plant material (12.3\%). The effluent, containing the "start" microbial community, was sieved on a $1 \mathrm{~mm}$ filter to remove the larger particles. In each set of experiments 3 control reactors, containing only the "start" inoculum, were included. The various reactors were operated in 3 parallel biological replicates. The reactors were sealed with butyl septa and aluminum crimps and the headspace was replaced with flushing by $\mathrm{N}_{2}$ gas (Messer nitrogen 4.5) for $5 \mathrm{~min} . \mathrm{H}_{2}$ and $\mathrm{CO}_{2}$ were injected manually and daily into the head-space with disposable plastic syringes. The reactors received varying volumes of daily $\mathrm{H}_{2}$ doses, which were nominally 20,40 , and $60 \mathrm{~mL}$ of pure $\mathrm{H}_{2}$ gas, respectively. The amount of the injected gas was verified by gas chromatography (GC) as corresponding to 18.0, 31.5 and $43.5 \mathrm{v} / \mathrm{v} \%$ actual initial $\mathrm{H}_{2}$ concentration in the head-space. The gas composition in the reactor head-space was determined daily by GC and after the measurements the reactors were degassed by purging with $\mathrm{N}_{2}$ for $5 \mathrm{~min}$ and the internal pressure was adjusted to atmospheric level. The reactors were incubated in a thermostated rotary shaker at $55^{\circ} \mathrm{C}$.

\subsection{Volatile Organic Acid Analysis}

Samples for organic acid analysis were pretreated according to Szuhaj et al. [28]. 
The concentrations of volatile organic acids were measured with HPLC (Hitachi Chromaster) equipped with a refractive index detector Chromaster 5450. The separation was performed on an Agilent Hi-Plex $\mathrm{H}$ column. The temperature of the column and detector were $50{ }^{\circ} \mathrm{C}$ and $41^{\circ} \mathrm{C}$, respectively. The eluent was $0.02 \mathrm{M} \mathrm{H}_{2} \mathrm{SO}_{4}\left(0.6 \mathrm{~mL} \cdot \mathrm{min}^{-1}\right)$.

\subsection{Gas Composition Analysis}

The gas composition of the reactor headspace was measured every day by GC. The $\mathrm{CH}_{4}$ and $\mathrm{H}_{2}$ contents were determined with an Agilent 6890N GC (Agilent Technologies, Santa Clara, CA, USA) equipped with an HP Molesive $5 \AA(30 \mathrm{~m} \times 0.53 \mathrm{~mm} \times 25 \mu \mathrm{m})$ column and a TCD detector. The temperature of the injector was $150{ }^{\circ} \mathrm{C}$ and application was made in split mode 1.1:1. The column temperature was maintained at $47^{\circ} \mathrm{C}$. The carrier gas was Linde $\mathrm{HQ}$ argon 5.0, with the flow rate set at $9.6 \mathrm{~mL} \cdot \mathrm{min}^{-1}$.

The amount of $\mathrm{CO}_{2}$ was determined with a Shimadzu GC 2010 (Shimadzu Corporation) equipped with a TCD detector and a HP PlotQ $(30 \mathrm{~m} \times 0.5 \mathrm{~mm} \times 40 \mu \mathrm{m})$ column. The chromatograph was operated in split injection mode (rate 4:1). The temperature of the inlet was $200^{\circ} \mathrm{C}$. The column and the detector temperature were maintained at $90{ }^{\circ} \mathrm{C}$ and $150{ }^{\circ} \mathrm{C}$, respectively. The carrier gas was Messer nitrogen 4.5 at $1.25 \mathrm{~mL} \cdot \mathrm{min}^{-1}$. The samples were injected with the help of a gastight microsyringe (Hamilton). The conversion efficiency of $\mathrm{H}_{2}$ to $\mathrm{CH}_{4}$ was calculated by the modified theoretical equation $[28,30,36]$.

$$
\eta=\frac{\left(\mathrm{r}_{\mathrm{CH}_{4} A}-\mathrm{r}_{\mathrm{CH}_{4} B}\right)}{\left(\mathrm{r}_{\mathrm{H}_{2} \mathrm{~A}}-\mathrm{r}_{\mathrm{H}_{2} \mathrm{D}}\right) \times 4} \times 100
$$

where " $A$ " is the experimental reactor and

$\eta=$ conversion efficiency of $\mathrm{H}_{2}$ to $\mathrm{CH}_{4}(\%)$

$\mathrm{r}_{\mathrm{CH}_{4} A}=\mathrm{CH}_{4}$ production of reactor $\mathrm{A}\left(\mathrm{mL} \cdot \mathrm{L}^{-1} \cdot \mathrm{d}^{-1}\right)$

$\mathrm{r}_{\mathrm{CH}_{4} B}=\mathrm{CH}_{4}$ production of control reactor $\left(\mathrm{mL} \cdot \mathrm{L}^{-1} \cdot \mathrm{d}^{-1}\right)$

$\mathrm{r}_{\mathrm{H}_{2} \mathrm{~A}}=$ injected amount of $\mathrm{H}_{2}$ to reactor $\mathrm{A}\left(\mathrm{mL} \cdot \mathrm{L}^{-1} \cdot \mathrm{d}^{-1}\right)$

$\mathrm{r}_{\mathrm{H}_{2} \mathrm{D}}=$ residual amount of $\mathrm{H}_{2}$ in reactor $\mathrm{A}\left(\mathrm{mL} \cdot \mathrm{L}^{-1} \cdot \mathrm{d}^{-1}\right)$

\subsection{Determination of Fermentation Parameters}

oDM: The organic dry matter content was quantified by drying the biomass at $105^{\circ} \mathrm{C}$ overnight and weighing the residue, giving the dry mass content. Further heating of this residue at $550{ }^{\circ} \mathrm{C}$ provided the organic dry matter (oDM) content.

pH: The $\mathrm{pH}$ was measured with a Radelkis OP-211/2 equipped with an OP-0808P pH electrode immediately after the daily GC analysis.

\subsection{Total DNA Isolation for Metagenomics}

The composition of the microbial community was investigated twice during the experimental period from each reactor and controls, i.e., at the starting point (inoculation) and at the end of cultivation. For total community DNA isolation $2 \mathrm{~mL}$ samples were taken from each reactor. DNA extractions were carried out using the Zymo Research Fecal DNA kit (D6010, Zymo Research, Irvine, CA, USA). Bead beating was performed by Vortex Genie 2, bead size: $0.1 \mathrm{~mm}$, beating time: $15 \mathrm{~min}$, beating speed: max, and in other details the Zymo Research kit protocol was followed. The quantity of DNA was estimated using a NanoDrop ND-1000 spectrophotometer (NanoDrop Technologies, Wilmington, NC, USA) and a Qubit 2.0 Fluorometer (Life Technologies, Carlsbad, CA, USA). DNA purity was tested by agarose gel electrophoresis and on an Agilent 2200 TapeStation instrument (Agilent Technologies).

\subsection{Shotgun Sequencing}

The recommendations of the Ion Torrent $\mathrm{PGM}^{\mathrm{TM}}$ sequencing platform were closely followed (Life Technologies, Carlsbad, CA, USA). The preparation of sample libraries was done according to the Life Technologies IonXpress fragment plus library protocol (4471269). Ion device library quantitation kit (4468802) and Step One Real Time PCR 
(Applied Biosystems) were used to quantify the samples. The Ion PGM Template OT2 200 kit (4480974) was used with OneTouch 2 and Ion OneTouch ES devices. The barcoding was done by IonXpress barcode kit (4471250). Sequencing was performed with Ion PGM 200 Sequencing kit (4474004) on Ion Torrent PGM 316 chip.

Raw sequences are available on NCBI Sequence Read Archive (SRA) under the submission number: PRJNA625695.

\subsection{Raw Sequence Filtering}

The Galaxy Europe server was employed to pre-process the raw sequences (i.e., sequence filtering, mapping, quality checking) [37]. Low-quality reads were filtered by Prinseq [38] (min. length: 60; min. score: 15; quality score threshold to trim positions: 20; sliding window used to calculated quality score:1). Filtered sequences were checked with FastQC.

\subsection{Read-Based Metagenome Data Processing and Statistical Analysis}

The filtered sequences were further analyzed by Kaiju, applying the default greedy run mode on Progenomes2 database $[39,40]$. MEGAN6 was used to investigate microbial communities and export data for statistical calculation. The results were plotted with iTOL (Interactive Tree of Life) [41]. The microbial changes of the communities were estimated as the $\log 2$ fold changes $(\log 2 \mathrm{FC})$ :

$$
\log 2 \mathrm{FC}=\log 2\left(\frac{\text { abundance } \mathrm{X}}{\text { abundance START/CONTROL }}\right)
$$

\section{Results}

3.1. Methanogenesis by $\mathrm{H}_{2}$ and $\mathrm{H}_{2}+\mathrm{CO}_{2}$

The mixed AD community was first supplied with various amounts of $\mathrm{H}_{2}$ in order to eliminate the dissolved $\mathrm{CO}_{2} / \mathrm{HCO}_{3}{ }^{-}$in the $\mathrm{AD}$ fermentation effluent (Figure 1).

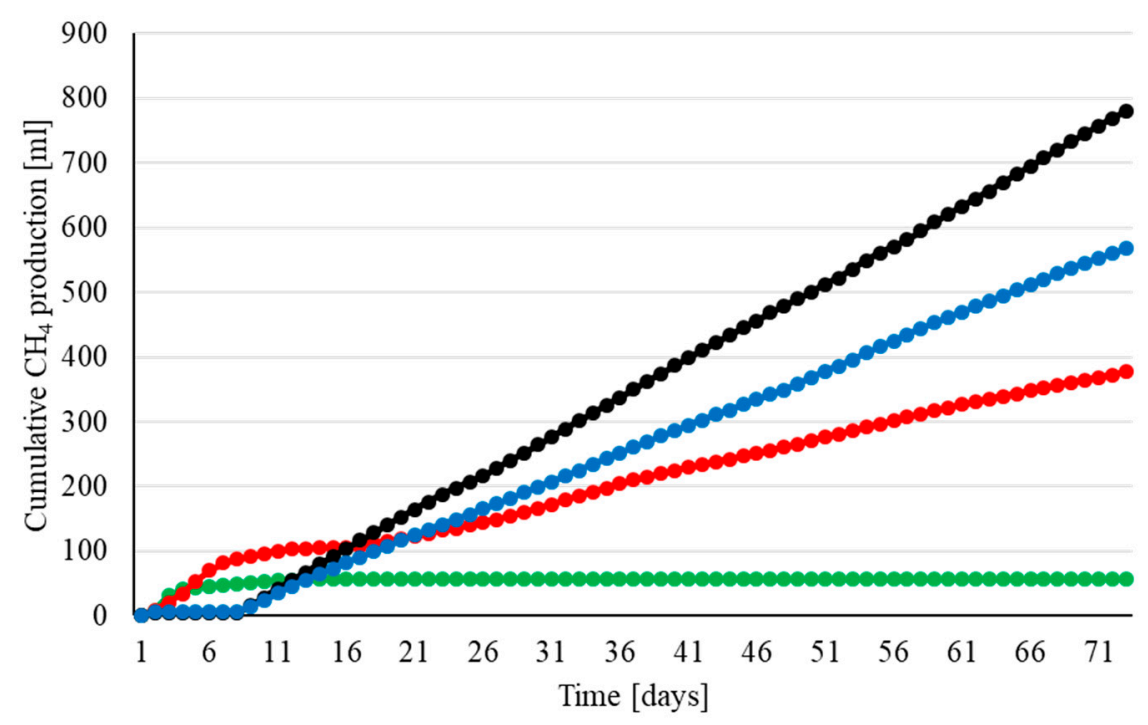

Figure 1. Cumulative biomethane productions in time from $20 \mathrm{~mL}$ nominal $\mathrm{H}_{2}$ volume $\left(=18.0 v / v \% \mathrm{H}_{2}\right.$, red curve), $40 \mathrm{~mL}$ nominal $\mathrm{H}_{2}$ volume (=31.5 $/ / \mathrm{v}_{2} \mathrm{H}_{2}$, blue curve) and $60 \mathrm{~mL}$ nominal $\mathrm{H}_{2}$ volume (= $43.5 v / v \% \mathrm{H}_{2}$, black curve) and concomitant stoichiometric $\mathrm{CO}_{2}$. The control, i.e., only daily $\mathrm{N}_{2}$ gas replacement of the head-space, is shown in green. The symbol sizes indicate the error of measurement.

The control samples (green curve) evolved a small amount of residual $\mathrm{CH}_{4}$ during day $1-2$, but $\mathrm{CH}_{4}$ generation ceased afterwards indicating the cessation of biogas formation due to the preceding depletion of degradable organic substrates. The reactors received varying volumes of daily $\mathrm{H}_{2}$ doses, which were nominally 20,40 , and $60 \mathrm{~mL}$ of pure $\mathrm{H}_{2}$ gas, shown 
with red, blue and black curves, respectively, corresponded to 18.0, 31.5, and $43.5 v / v \%$ actual initial $\mathrm{H}_{2}$ concentration in the head-space. The daily $\mathrm{H}_{2}$ doses were completely consumed within $24 \mathrm{~h}$ in all reactors. The microbial community quickly consumed the dissolved $\mathrm{CO}_{2} / \mathrm{HCO}_{3}{ }^{-}$as well, indicating high biological activity. The reactors receiving $18 v / v \%$ of $\mathrm{H}_{2}$ started to produce $\mathrm{CH}_{4}$ intensively, implying sufficient level of a hydrogenotrophic methanogen activity for the bioconversion reaction. After about a week of daily $\mathrm{H}_{2}$ feeding of the reactors the $\mathrm{CH}_{4}$ evolution began to cease and the cumulative $\mathrm{CH}_{4}$ production curve levelled off. By this time the $\mathrm{CO}_{2}$ completely disappeared from the headspace of the reactors (Figure 2). A combination of these observations was indicative of methanogenesis limitation as a consequence of $\mathrm{CO}_{2} / \mathrm{HCO}_{3}{ }^{-}$depletion by hydrogenotrophic methanogenesis. The situation was remedied by the injection of $6.5 v / v \% \mathrm{CO}_{2}$ together with the daily $\mathrm{H}_{2}$ dosage (Figure 2) on days 8-14 and 22 as indicated by the arrows.

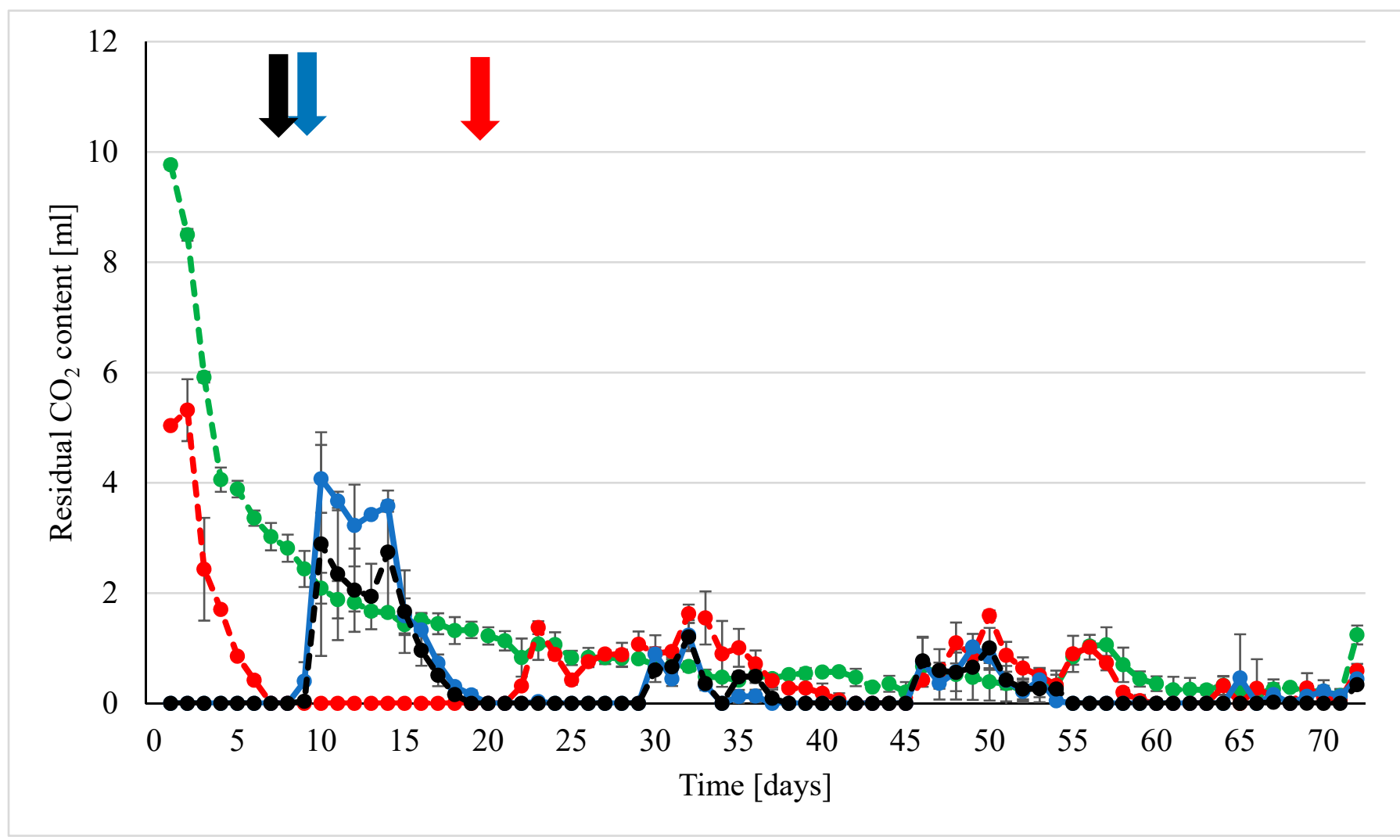

Figure 2. The residual $\mathrm{CO}_{2}$ levels measured in the reactors' head-space. Color codes as in Figure 1: green $=$ control reactors, red = low $\mathrm{H}_{2}$ daily dosage ( $20 \mathrm{~mL} \mathrm{H}_{2}$ nominal volume), blue = medium $\mathrm{H}_{2}$ daily dosage $\left(40 \mathrm{~mL} \mathrm{H}_{2}\right.$ nominal volume), black = high daily $\mathrm{H}_{2}$ dosage $\left(60 \mathrm{~mL} \mathrm{H}_{2}\right.$ nominal volume). The arrows indicate the time points when excess $\mathrm{CO}_{2}$ was delivered in order to remedy system imbalance.

This effectively restored $\mathrm{CH}_{4}$ production, although the excess $\mathrm{CO}_{2}$ supply resulted in a transient accumulation of $\mathrm{CO}_{2}$ in the headspace. Henceforth, a 4:1 volumetric mixture of $\mathrm{H}_{2}$ and $\mathrm{CO}_{2}$ was injected daily into the head-space of the reactors. Steady $\mathrm{CH}_{4}$ production, without detectable $\mathrm{H}_{2}$ or $\mathrm{CO}_{2}$, was maintained throughout the rest of the 71-day long experiment, demonstrating sustainable bioconversion of $\mathrm{H}_{2} / \mathrm{CO}_{2}$ to $\mathrm{CH}_{4}$. The alterations in the $\mathrm{pH}$ of the reactor content reflected and corroborated the postulated sequence of events. Following week 2 , a significant $\mathrm{pH}$ elevation was noted in the reactors receiving $18 \mathrm{v} / \mathrm{v} \%$ of $\mathrm{H}_{2}$, which quickly reached an alarming level above $\mathrm{pH}=9$ (Figure 3) on weeks 2 and 3 . The injection of $\mathrm{CO}_{2}$ slowly returned the $\mathrm{pH}$ level to normal, corroborating the essential role of $\mathrm{CO}_{2} / \mathrm{HCO}_{3}{ }^{-}$in maintaining and regulating the buffering capacity in these systems. 


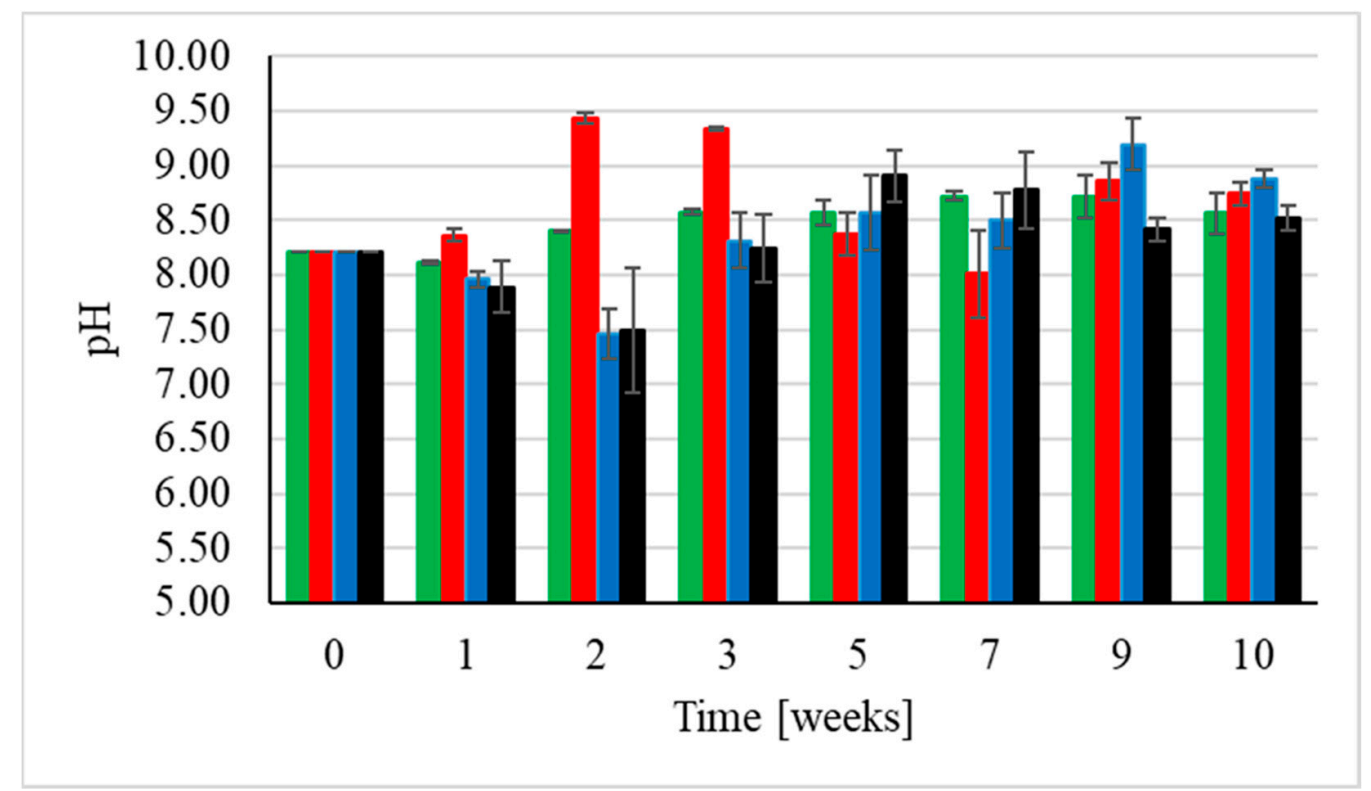

Figure 3. The alterations in $\mathrm{pH}$ values of the aqueous phase of the reactors: green $=$ control reactors, red $=20 \mathrm{~mL} \mathrm{H}_{2}$ nominal volume daily dosages, blue $=40 \mathrm{~mL} \mathrm{H}_{2}$ nominal volume daily dosages, black $=60 \mathrm{~mL} \mathrm{H}_{2}$ nominal volume daily dosages and concomitant stoichiometric $\mathrm{CO}_{2}$.

The reactors receiving higher $\mathrm{H}_{2}$ doses ( 31.5 or $43.5 v / v \%$ ) showed a substantially distinct behavior. In these reactors $\mathrm{CH}_{4}$ evolution did not commence upon $\mathrm{H}_{2}$ addition and $\mathrm{CO}_{2}$ was not detectable in the headspace even after the first day. Nevertheless, the injected $\mathrm{H}_{2}$ was consumed completely by the microbial community. Pursuing possible bioconversion product(s) other than $\mathrm{CH}_{4}$ revealed that the microbes utilized the $\mathrm{H}_{2}$ and $\mathrm{CO}_{2}$ in the reactors for syntrophic acetate production via homoacetogenesis [42]. Accumulation of considerable amounts of acetate (Figure 4) indicated the predominance of this pathway in these reactors. In line with this mechanism was the substantial $\mathrm{pH}$ drop on week 2 (Figure 3). Overdosed (9.9 and $13.9 \mathrm{v} / \mathrm{v} \%$ ) injection of $\mathrm{CO}_{2}$ (Figure 2) successfully balanced the $\mathrm{pH}$ back to near normal level for methanogenesis in these reactors. Accordingly, steady $\mathrm{CH}_{4}$ production started (days 8-10) and daily stoichiometric gas delivery of $\mathrm{H}_{2}$ and $\mathrm{CO}_{2}$, drifted the system away from volatile fatty acid (VFA) biosynthesis to hydrogenotrophic methanogenesis (Figures 1-3). All reactors were eventually stabilized in the biomethane production mode and maintained their stable operation for the rest of the experimental period. Acetate and other VFAs were barely detectable in these reactors (Figure 4).

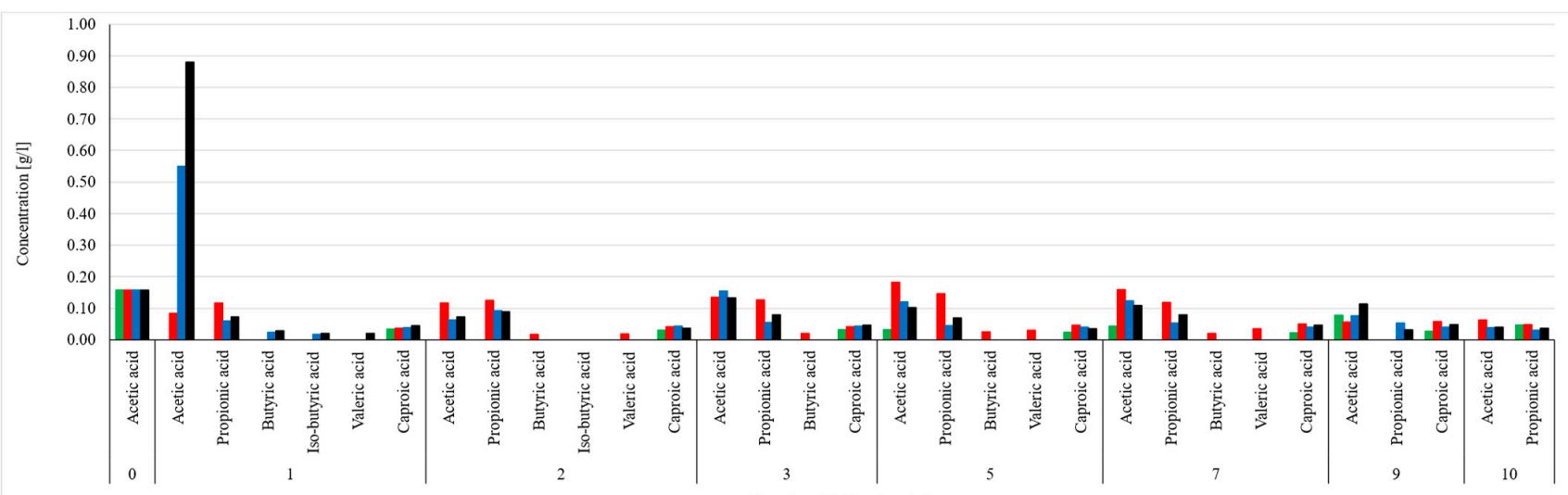

Figure 4. The volatile fatty acids (VFA) productions of the P2M reactors: green = control reactors, red $=20 \mathrm{~mL} \mathrm{H}_{2}$ nominal volume daily dosages, blue $=40 \mathrm{~mL} \mathrm{H}_{2}$ nominal volume daily dosages, black $=60 \mathrm{~mL} \mathrm{H}_{2}$ nominal volume daily dosages and concomitant stoichiometric $\mathrm{CO}_{2}$. 


\subsection{Metagenomic Analyses}

The microbial community of the thermophilic digestate was diverse, although the majority of the identified genera were present in low relative abundance $(<1 \%)$ (Figure 5$)$. Feeding the community with only $\mathrm{H}_{2} / \mathrm{CO}_{2}$ daily, acted as strong selection pressure on the community by the end of the 71-day long P2M experiment. In spite of the apparent high initial microbial diversity, a limited number of taxa survived the P2M experimental conditions (Table 1) leading to the substantial enrichment of the successful survivors.

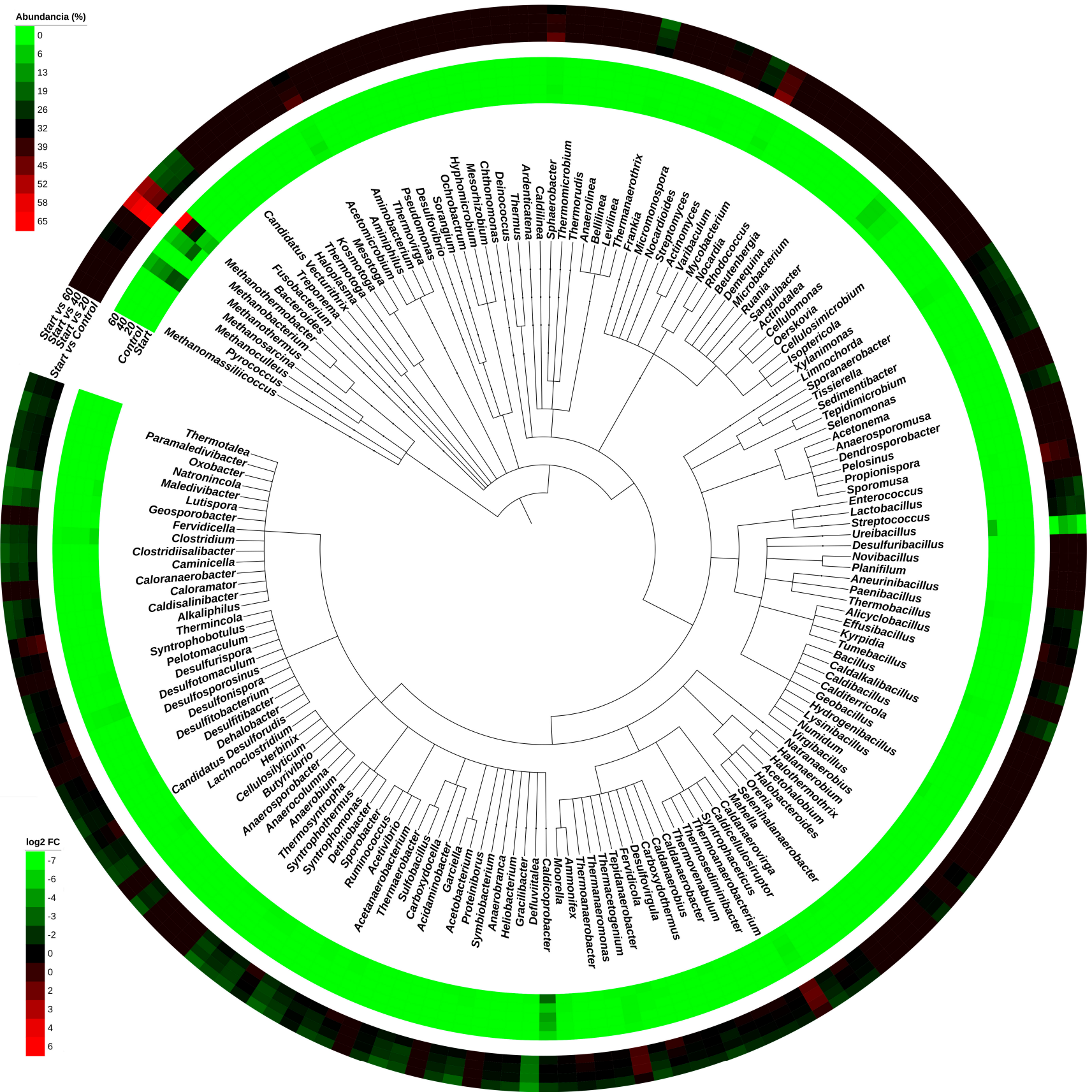

Figure 5. The microbial diversity map is plotted in the central taxonomic tree and the names of genera corresponding to the branches. The average relative abundances of the taxa in the various reactors are shown in the set of the outer 5 rings: starting community; control (= no $\mathrm{H}_{2}$ feeding) community; 20, 40, and $60 \mathrm{~mL} \mathrm{H}_{2}$ nominal volume daily dosages, respectively; color scale in the upper left corner. Set of 4 outermost rings: comparison of the logarithmic fold change (log2FC) values between the start community and the control, 20, 40, and $60 \mathrm{~mL} \mathrm{H}_{2}$ nominal volume daily dosages, respectively, and concomitant stoichiometric $\mathrm{CO}_{2}$ (color scale in the lower left corner). 
Table 1. The changes in relative abundances of the 23 most abundant microbial taxa upon various treatments. START: composition of the initial thermophilic AD effluent; Control: only daily $\mathrm{N}_{2}$ gas replacement of the head-space; $20 \mathrm{~mL}$ $\mathrm{H}_{2}$ reactor: $20 \mathrm{~mL}$ nominal $\mathrm{H}_{2}$ volume $\left(=18.0 v / v \% \mathrm{H}_{2}\right) ; 40 \mathrm{~mL} \mathrm{H}_{2}$ reactor: $40 \mathrm{~mL}$ nominal $\mathrm{H}_{2}$ volume $\left(=31.5 v / v \% \mathrm{H}_{2}\right)$; $60 \mathrm{~mL} \mathrm{H}_{2}$ reactor: $60 \mathrm{~mL}$ nominal $\mathrm{H}_{2}$ volume $\left(=43.5 \mathrm{v} / \mathrm{v} \% \mathrm{H}_{2}\right)$ and concomitant stoichiometric $\mathrm{CO}_{2}$. Color codes in the cells of taxon names are as follows: red-Archaea genera; white-the abundance was not affected by $\mathrm{H}_{2} / \mathrm{CO}_{2}$ addition; yellow-the abundance of genera decreased at all $\mathrm{H}_{2} / \mathrm{CO}_{2}$ concentrations as a result of starvation stress; green-genera responding positively to starvation and to moderate $\mathrm{H}_{2} / \mathrm{CO}_{2}$ daily dosage. Red background color in the log2FC cells indicates enrichment, blue background color denotes diminishing tendency for the given taxon. The most striking changes are the boxed in heavy borderlines.

\begin{tabular}{|c|c|c|c|c|c|}
\hline Taxon & START & Control & $20 \mathrm{~mL} \mathrm{H}_{2}$ Reactor & $40 \mathrm{~mL} \mathrm{H}_{2}$ Reactor & $60 \mathrm{~mL} \mathrm{H}_{2}$ Reactor \\
\hline Methanosarcina & 21.69 & 22.80 & 15.24 & 13.70 & 9.35 \\
\hline Caldicoprobacter & 19.89 & 7.12 & 12.32 & 9.90 & 4.20 \\
\hline Ureibacillus & 9.10 & 0.05 & 0.19 & 0.12 & 0.05 \\
\hline Methanothermobacter & 8.37 & 6.60 & 29.47 & 37.53 & 65.26 \\
\hline Clostridium & 4.52 & 1.48 & 1.02 & 1.01 & 0.78 \\
\hline Lutispora & 2.28 & 0.29 & 0.17 & 0.16 & 0.13 \\
\hline Desulfotomaculum & 1.80 & 2.18 & 1.41 & 1.30 & 0.78 \\
\hline Moorella & 1.53 & 1.26 & 0.85 & 0.73 & 0.43 \\
\hline Herbinix & 1.35 & 0.50 & 0.27 & 0.28 & 0.22 \\
\hline Lysinibacillus & 1.33 & 0.10 & 0.10 & 0.10 & 0.10 \\
\hline Limnochorda & 1.31 & 1.09 & 0.63 & 0.50 & 0.23 \\
\hline Acetomicrobium & 1.28 & 3.11 & 1.54 & 1.32 & 0.78 \\
\hline Bacillus & 1.23 & 0.50 & 0.35 & 0.31 & 0.16 \\
\hline Paenibacillus & 1.16 & 0.60 & 0.40 & 0.39 & 0.23 \\
\hline Syntrophomonas & 1.03 & 0.36 & 0.22 & 0.21 & 0.13 \\
\hline Tepidanaerobacter & 1.01 & 0.65 & 0.34 & 0.25 & 0.17 \\
\hline Syntrophaceticus & 0.57 & 1.48 & 1.79 & 1.55 & 0.76 \\
\hline Sphaerobacter & 0.57 & 1.60 & 0.67 & 0.76 & 0.36 \\
\hline Thermacetogenium & 0.55 & 1.11 & 1.24 & 1.18 & 0.51 \\
\hline Mycobacterium & 0.37 & 1.69 & 0.80 & 0.78 & 0.55 \\
\hline Methanobacterium & 0.28 & 19.99 & 10.99 & 9.30 & 5.72 \\
\hline Actinotalea & 0.10 & 5.09 & 5.32 & 5.39 & 2.10 \\
\hline Cellulomonas & 0.10 & 2.44 & 2.65 & 2.66 & 1.05 \\
\hline
\end{tabular}

Within the kingdom Bacteria the genus Caldicoprobacter turned out to be the most abundant $(19.9 \%)$ in the starting community, i.e., in the fermentation effluent of the thermophilic AD plant. These hydrolyzing bacteria belong in the order Clostridia and class Firmicutes and degrade various carbohydrates, e.g., arabinose, xylose, ribose, fructose [43], and proteins via their active serine protease [44]. The second most abundant genus in the kingdom Bacteria was Ureibacillus. These bacteria can also carry out a number of heterotrophic decomposition pathways [45-47]. Additional predominating members of the thermophilic anaerobic community were the genera Clostridium and Lutispora with relative abundances of 4.5 and $2.3 \%$, respectively. These genera are routinely found in biogas communities [48,49], together with the less abundant genera Desulfotomaculum $(1.8 \%)$ and Moorella (1.5\%) (Table 1).

Members of the genus Methanosarcina were initially the predominant ones among methanogens with relative abundance of $21.7 \%$. Methanosarcina is the only known genus, which is able to carry out all three methanogenic pathways, i.e., acetoclastic, hydrogenotrophic, and methylotrophic $\mathrm{CH}_{4}$ biosynthesis. This versatile capability makes them the most frequently detected methanogens in many biogas producing systems [7,15]. In line with the metabolic versatility, they showed excellent survival competence upon starvation, the relative abundance in the control reactor was $22.8 \%$. Next in abundance among the initial methanogens was the genus Methanothermobacter $(8.4 \%)$, a typically hydrogenotrophic methanogen [50]. They endured the starvation just as well as the genus Methanosarcina, and eventually became the most predominant methanogens in all reactors fed with $\mathrm{H}_{2} / \mathrm{CO}_{2}$, greatly outnumbering the other two methanogenic genera and therefore substantially contributing to the P2M conversion. It is noteworthy, that the relative abundance of the genus Methanothermobacter increased with the daily $\mathrm{H}_{2}$ doses injected into the reactors while both Methanosarcina and Methanobacterium appeared to respond on the contrary, i.e., their relative abundances apparently decreased at elevated $\mathrm{H}_{2}$ addition (Table 1 ). Since these 
abundance values are relative ones, they indicate the level of competition for $\mathrm{H}_{2}$ among the methanogens rather than the absolute number or survival vigor of these Archaea.

The overall rearrangement of the microbial community as a result of $\mathrm{H}_{2} / \mathrm{CO}_{2}$ feeding may not look spectacular at first glance (Figure 5, outermost rings). This is due to the fact that sequencing of the samples allowed the identification of numerous taxa present in very low abundance, i.e., $<0.1 \%$ in the microbial communities. The changes in the scarcely present microbes upon various treatments are difficult to assess, therefore these were not considered in the comparative analyses. Important changes were recognized upon a closer look (Table 1 ) of the 23 most abundant taxa present in the starting microbial community. Although fresh organic substrate was not delivered into the reactors, some of the heterotrophic Bacteria managed to survive and flourish in spite of the lack of added organic substrates for their heterotrophic growth.

A marked reorganization of the microbial community took place, when the microbes were subjected to starvation, i.e., neither external organic substrate nor $\mathrm{H}_{2} / \mathrm{CO}_{2}$ was available to support their life. Comparison of the "start", i.e., thermophilic AD effluent, microbial community with the "control", i.e., thermophilic AD effluent incubated at $55^{\circ} \mathrm{C}$, with daily replacement of the headspace with $\mathrm{N}_{2}$ gas, clearly indicated a fight for survival within the community (Table 1 , columns 2 and 3 ).

The regulatory effects of $\mathrm{H}_{2}$ and/or $\mathrm{H}_{2} / \mathrm{CO}_{2}$, together with the lack of added organic substrates, manifested themselves in the genera Ureibacillus ( $\log 2 \mathrm{FC}=-7.6)$, Lutispora $(\log 2 \mathrm{FC}=-3.9)$, Herbinix $(\log 2 \mathrm{FC}=2.4)$, Clostridium $(\log 2 \mathrm{FC}=-2.3)$, Bacillus $(\log 2 \mathrm{FC}=-1.3)$, Tepidanaerobacter $(\log 2 \mathrm{FC}=-2.0)$ among Bacteria. Ureibacilli have been found frequently in thermophilic aerobic poultry waste treatment sites [51]. Similarly, the genera Lysinobacillus and Paenibacillus are typical components of the poultry manure microbiota $[52,53]$. These apparently "outlier" bacteria (taxon names are highlighted in yellow in Table 1) could have therefore infiltrated the thermophilic $\mathrm{AD}$ community from the AD substrate, which contained poultry meat processing waste (Figure 6).

The declining representation of homoacetogens, e.g., genus Syntrophomonas $(\log 2 \mathrm{FC}=-2.5)$ [54], indicated a shift from syntrophic acetate oxidation (SAO) to hydrogenotrophic methanogenesis in the reactors fed with increasing $\mathrm{H}_{2} / \mathrm{CO}_{2}$ loading. In contrast, the SAO genus Actinotalea acclimated excellently to the starvation condition and subsequently to the P2M conditions. Similarly, other SAOB genera, such as Syntrophaceticus and Thermoacetogenium [55] emerged substantially from the diverse group of low abundant taxa in the starting community upon starvation and remained stable members of the community, although virtually unaffected by the amount of daily $\mathrm{H}_{2}$ dosage (taxon names are highlighted in green in Table 1). Others (taxon names are highlighted in white in Table 1 ) remained unaffected by the presence of $\mathrm{H}_{2} / \mathrm{CO}_{2}$ in their environment.

Interestingly, the methanogens (taxon names are highlighted in red in Table 1) responded differently to the changing environment. The genus Methanosarcina, a predominant methanogen in the starting community, was not affected by the starvation, but became slightly inhibited by the daily dosage of $\mathrm{H}_{2} / \mathrm{CO}_{2}(\log 2 \mathrm{FC}=-0.8)$, although it should be noted again that only relative abundance values were compared in this study. Increasing the $\mathrm{H}_{2}$ supply triggered an apparent drop in the number of Methanobacteria, but their average abundance was at the respectable $\log 2 \mathrm{FC}=4.9$. The hydrogenotrophic methanogen Archaea (HMA), belonging in the genus Methanothermobacter became the absolute predominant taxon, its relative abundance increased from $8.4 \%$ in the starting community up to $65.3 \%$ in the reactors receiving $43.5 v / v \% \mathrm{H}_{2}+10.9 v / v \% \mathrm{CO}_{2}$ every day (Figure 6). 


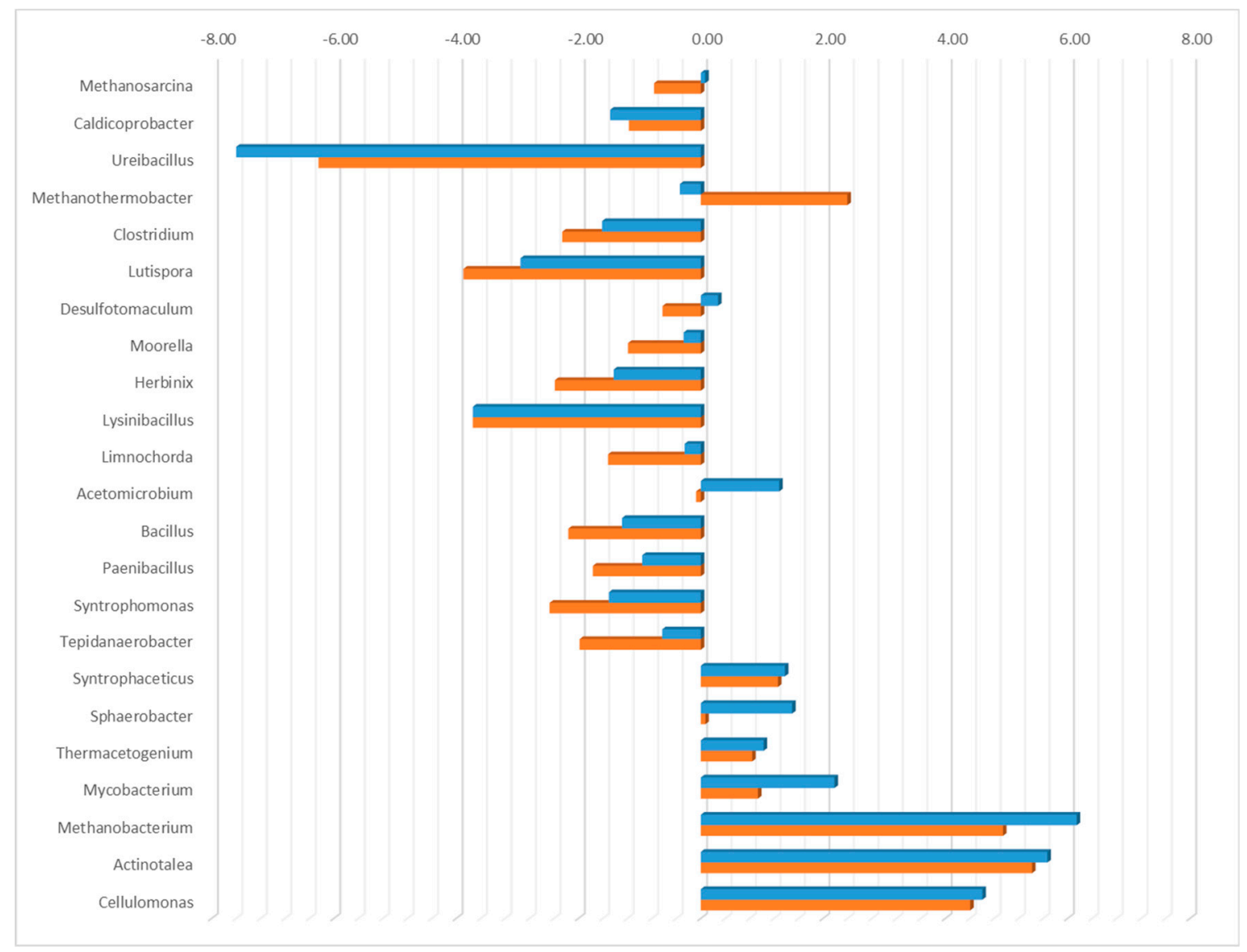

Figure 6. The logarithmic fold change $(\log 2 \mathrm{FC})$ abundance alterations in the most abundant 23 genera at the end of the experiment. The control vs. starting community log2FC values are plotted in green columns, and the log2FC between the control vs. the average of $\mathrm{H}_{2} / \mathrm{CO}_{2}$-fed reactors are shown in red columns.

\section{Discussion}

Signatories of the Paris agreement [56] pledged to exercise joint efforts and limit the global climate change to below $2{ }^{\circ} \mathrm{C}$, a challenging undertaking for mankind. Among the measures to be implemented, the expanded use of renewable energy carriers to replace the currently predominating fossil ones has high priority. There are a number of technical tasks to solve and obstacles to overcome along this road, but photovoltaics, wind, and hydro power technologies have already gained momentum and increased appreciably the contribution to the conversion of the energy palette. These technologies produce renewable electricity often in a fluctuating and unpredictable fashion, depending on the environmental conditions. The electricity grids experience difficulties in handling this irregular input without major losses. The power-to-gas (P2G) or power-to-methane (P2M) technology offers a solution by converting the excess renewable electricity to $\mathrm{H}_{2}$ or $\mathrm{CH}_{4}$ via P2G or P2M, respectively [57]. $\mathrm{H}_{2}$ is a carbon-free energy carrier for the future, $\mathrm{CH}_{4}$ seems to be an excellent second choice and an easier target due to the existing elaborated transport and storage networks for "natural gas", which is essentially fossil $\mathrm{CH}_{4}$.

Several approaches have been proposed to realize P2M [15] using biological systems as catalyst of the $\mathrm{CO}_{2}$ reduction to $\mathrm{CH}_{4}$. They all employ hydrogenotrophic methanogenic Archaea (HMA), which carry out the required biochemical reaction in their natural environment to sustain their life [58], within the biogas producing anaerobic microbial communities [59]. HMAs can accomplish $\mathrm{CO}_{2}$ reduction both in microbiologically pure cultures and as parts of a larger microbial community. In a mixed community the provision of only $\mathrm{H}_{2}$ or $\mathrm{H}_{2} / \mathrm{CO}_{2}$ acts as selection pressure in the process. Under mesophilic conditions $[28,35]$ the reactors fed solely with $\mathrm{H}_{2}$, consumed the dissolved $\mathrm{CO}_{2} / \mathrm{HCO}_{3}{ }^{-}$and $\mathrm{CH}_{4}$ evolution 
ceased after 26-28 days. Correcting the conditions by daily injection of stoichiometric $\mathrm{H}_{2} / \mathrm{CO}_{2}$ in the head-space restored the P2M process, which could be maintained for an extended period of time. The daily doses of $\mathrm{H}_{2} / \mathrm{CO}_{2}$ were completely consumed within 16-20 h.

In the present study the same overall workflow was tested under thermophilic $\left(55^{\circ} \mathrm{C}\right)$ conditions. Elevation of the reaction temperature accelerated the performance of the HMAs in the mixed microbial community. The reactors supplied with 31.5 or $43.5 \% \mathrm{H}_{2}$ did not evolve $\mathrm{CH}_{4}$ (Figure 1), but converted the $\mathrm{H}_{2} / \mathrm{CO}_{2}$ to primarily acetate (Figure 4 ), which suggested a homoacetogenic reaction pathway for $\mathrm{H}_{2}$ metabolism instead of the expected $\mathrm{CH}_{4}$ evolution. Apparently, the dissolved $\mathrm{CO}_{2} / \mathrm{HCO}_{3}{ }^{-}$was used as carbon source in the acetate biosynthesis as indicated by both the VFA profile and the increased $\mathrm{pH}$ by the end of day 7. Similar events were observed only after 3-4 weeks of daily $\mathrm{H}_{2}$ injection under mesophilic conditions [28].

Distinct behavior was observed at low daily $\mathrm{H}_{2}$ dosage, i.e., $18 \%$ of $\mathrm{H}_{2}$ in the headspace at the time of gas injection. The $\mathrm{H}_{2}$ also wholly disappeared from the head-space within $24 \mathrm{~h}$ and $\mathrm{CH}_{4}$ evolution commenced. Accumulation of VFAs and concomitant elevation of $\mathrm{pH}$ was not observed in these reactors indicating that the P2M reaction took place already during this first period of the experiment. By the end of week 2 probably most of the dissolved $\mathrm{CO}_{2} / \mathrm{HCO}_{3}{ }^{-}$was converted to $\mathrm{CH}_{4}$. Elevation of the $\mathrm{pH}$ was the first warning sign of system imbalance, which required action to restore stable $\mathrm{CH}_{4}$ production. Addition of stoichiometric daily $\mathrm{H}_{2} / \mathrm{CO}_{2}$ gas mixture resolved the problem.

In summary, the entire experimental timeline could be divided clearly into two phases. During the first period, the system responded quickly but in a distinct manner depending on the supplied $\mathrm{H}_{2}$ level and the dissolved $\mathrm{CO}_{2} / \mathrm{HCO}_{3}{ }^{-}$. When only low $\mathrm{H}_{2}$ volumes were injected into the reactors, i.e., $18 v / v \%, \mathrm{CH}_{4}$ evolution took place as expected. In contrast, addition of higher dosage of $\mathrm{H}_{2}$ inhibited $\mathrm{CH}_{4}$ formation completely from the start. Supplementation of a stoichiometric mixture of $\mathrm{H}_{2} / \mathrm{CO}_{2}$ yielded $87.5-95.5 \% \mathrm{CH}_{4}$ content during the second, stabilized P2M generation period in all reactors.

A comparison of the performance using a fed-batch and " $\mathrm{H}_{2}$ flow-through" reactor arrangement reveals the advantages of this P2M approach relative to the widely studied flow-through CSTR (continuous stirred-tank reactor) reactor configuration $[29,60,61]$ (Table 2). The fed-batch reactors upgraded the gas mixture to $95 \%$ bioCH$_{4}$ purity, which is close to the methane content required for direct injection into the natural gas grid. The yield of $\mathrm{CH}_{4}$ production from the injected $\mathrm{H}_{2}$ doubled in comparison to the values reported in $[29,62]$. The $\mathrm{H}_{2}$ injection rate reached $1300 \mathrm{~mL} \cdot \mathrm{L}^{-1} \cdot \mathrm{d}^{-1}$ in the reactors receiving the highest daily $\mathrm{H}_{2}$ dose and practically all the injected $\mathrm{H}_{2}$ was consumed by the microbial community for $\mathrm{CH}_{4}$ production. Moreover, the community apparently did not demand additional nutrients and/or minerals to sustain the biological activity of the enriched community as opposed to the systems utilizing a single HMA strain [22]. Taking these advantages together (Table 2), the fed-batch reactor arrangement and the intermittent gas feeding are recommended to become a novel, efficient P2M strategy as opposed to the flow-through P2M reactors. The increased residence time of $\mathrm{H}_{2} / \mathrm{CO}_{2}$ in contact with the aqueous bulk, containing the key living and actively functioning microbial catalysts, offers improved reactor performance although the technology is still far from being optimized. The costs of installation and operation of a fed-batch type P2M reactor would be substantially lower than that of a more sophisticated flow-through in situ or ex situ reactors equipped with online GC monitoring, fine-tuned process control, gas recirculation and management systems $[29,60,61]$.

The results corroborated the existence of a delicate balance between homoacetogenesis and methanogenesis, which is closely regulated by the $\mathrm{H}_{2}$ level within the system $[20,62,63]$. The time resolution of sampling, analytical measurements, and the complexity of the biochemical reactions in the system did not allow calculation of a precise mass balance in this system. Nevertheless, the data are compatible with the assumption that no additional metabolic pathway contributed considerably to the outcome of the P2M reaction by the 
mixed anaerobic thermophilic microbial communities. Detailed mapping of the events in time within the P2M reactors is needed as part of future research efforts to determine the boundaries and precise operational parameters, kinetics of dissolution of the gases and the development of $\mathrm{H}_{2}$ concentration gradients in the aqueous medium, etc. This is important for planning and management of the large scale P2M facilities based on mixed microbial systems, which should be competitive compared to the microbiologically well-defined P2M technologies using a pure HMA culture, particularly if the savings in operational costs are taken into account $[7,15,16]$.

Two effects causing selection pressure could be distinguished in these experiments. First, there was an alteration in the composition of the community composition as the result of starvation, i.e., incubation of the community under anaerobic condition for an extended period of time. Second and added to the starvation stress, the community responded to the addition of varying amounts of $\mathrm{H}_{2} / \mathrm{CO}_{2}$ so that certain genera were enriched, while others tended to diminish.

Among Bacteria, members of the genera Actinotalea $(\log 2 \mathrm{FC}=5.1)$ and Cellulomonas $(\log 2 \mathrm{FC}=2.4)$ were apparently the ones to respond successfully to the selection pressure brought about by starvation. Actinotalea are facultative anaerobes $[64,65]$ and thus carry out versatile metabolic pathways, whereas members of the genus Cellulomonas are superior in polysaccharide decomposition [66]. Since no organic material was supplied to support their heterotrophic growth, they could obtain organic substrate from the deceased members of the bacterial community. It is noteworthy that some genera present in low abundance $(\leq 0.5 \%)$ in the inoculum, e.g., Syntrophaceticus, Sphaerobacter, Thermacetogenium, and Mycobacterium also managed to avoid extinction under the starvation conditions [67-70]. Some of these and the genus Acetomicrobium exhibited similar behavior and are suspected or verified SAOBs [71].

The methanogenic genus, Methanosarcina, apparently did not suffer much from starvation stress (Table 1 ) and maintained its predominance in the AD community $[59,72,73]$. The abundance of the genus Methanothermobacter was also largely unaffected by the starvation stress. The hydrogenotrophic methanogen genus Methanobacterium took a surprisingly pronounced advantage under starvation condition, similarly to a recent finding at mesophilic temperature [49]. This taxon increased its relative abundance from a meager $0.3 \%$ to $20 \%$ under starvation conditions. Future metatranscriptomic studies should reveal the metabolic changes responsible for this outstanding behavior.

The changes in the abundances of the various taxa upon supplying the starving reactors with various daily dosages of $\mathrm{H}_{2} / \mathrm{CO}_{2}$ is of particular interest with regard to the development and microbiological management of a stable and efficient microbial P2M community. The differences in abundances between the microbial communities subjected to starvation stress and equally starved and $\mathrm{H}_{2} / \mathrm{CO}_{2}$-fed communities are expressed at logarithmic scale ( $\log 2$ fold change, Figure 6). The aim of this comparison was to separate the alterations in community composition due to $\mathrm{H}_{2} / \mathrm{CO}_{2}$ supply and starvation. It should therefore be noted that the lengths of the horizontal columns do not indicate absolute or relative abundances of any given taxon, these columns show only the differences between starving and $\mathrm{H}_{2} / \mathrm{CO}_{2}$-fed reactors. 


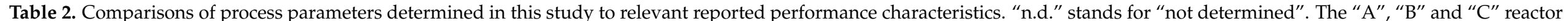
groups indicate the low, medium and high $\mathrm{H}_{2}$ daily dosage conditions as in Figure 1.

\begin{tabular}{|c|c|c|c|c|c|c|c|c|c|c|c|}
\hline & \multicolumn{2}{|c|}{ Bassani et al. (2015) } & \multicolumn{3}{|c|}{ Corbellini et al. (2018) } & \multicolumn{2}{|c|}{ Mulat et al. (2017) } & \multicolumn{4}{|c|}{ Present Work } \\
\hline & Control & $\mathrm{H}_{2}$ Added & Control & CSTR & UASB & Control & $\mathrm{H}_{2}$ Added & Control & "A" Reactor & "B" Reactor & "C" Reactor \\
\hline $\begin{array}{c}\text { Biogas } \\
\text { composition } \\
(\%)\end{array}$ & & & & & & & & & $\begin{array}{c}\text { After } \\
\text { stabilization }\end{array}$ & $\begin{array}{c}\text { After } \\
\text { stabilization }\end{array}$ & $\begin{array}{c}\text { After } \\
\text { stabilization }\end{array}$ \\
\hline $\mathrm{CH}_{4}$ & $67.1 \pm 0.8$ & $85.1 \pm 3.7$ & $69.2 \pm 1$ & $86.4 \pm 1.0$ & $91.0 \pm 2.0$ & $65.2 \pm 9.8$ & $89.4 \pm 0.4$ & $38.57 \pm 1.96$ & $87.48 \pm 5.86$ & $95.48 \pm 5.01$ & $94.13 \pm 4.90$ \\
\hline $\mathrm{CO}_{2}$ & $32.9 \pm 0.9$ & $6.6 \pm 0.9$ & $30.7 \pm 1$ & $10.7 \pm 3.6$ & $7.0 \pm 1.0$ & $34.8 \pm 9.8$ & $10.5 \pm 0.4$ & $61.43 \pm 8.51$ & $6.69 \pm 2.31$ & $1.56 \pm 1.00$ & $1.04 \pm 0.56$ \\
\hline $\mathrm{H}_{2}$ & 0.0 & $8.3 \pm 3.6$ & 0.0 & $3.5 \pm 1.5$ & $2.0 \pm 1.0$ & 0.0 & 0.0 & 0.0 & $2.99 \pm 1.61$ & $1.90 \pm 0.90$ & $3.49 \pm 2.50$ \\
\hline \multicolumn{12}{|l|}{$\begin{array}{c}\text { Gas } \\
\text { production } \\
\left(\mathrm{mL} \cdot \mathrm{L}^{-1} \cdot \mathrm{d}^{-1}\right)\end{array}$} \\
\hline $\mathrm{CH}_{4}$ & $247 \pm 27$ & $359 \pm 20$ & n.d. & n.d. & $352.53 \pm 53$ & 224 & 267 & $19.8 \pm 0.4$ & $131.2 \pm 14.4$ & $197.3 \pm 4.4$ & $270.7 \pm 7.4$ \\
\hline $\mathrm{CH}_{4}$ from $\mathrm{H}_{2}$ & 0 & 112.0 & 0.0 & n.d. & n.d. & 0.0 & 127.0 & 0.0 & 111.4 & 177.5 & 250.9 \\
\hline $\mathrm{CO}_{2}$ & $121 \pm 15$ & $28 \pm 5$ & n.d. & n.d. & $28.03 \pm 4.7$ & 119.6 & 31.4 & $31.0 \pm 3.3$ & $16.1 \pm 0.7$ & $11.1 \pm 0.8$ & $8.5 \pm 1.8$ \\
\hline $\begin{array}{l}\mathrm{H}_{2} \text { injection } \\
\text { rate } \\
\left(\mathrm{mL} \cdot \mathrm{L}^{-1} \cdot \mathrm{d}^{-1}\right)\end{array}$ & 0.0 & $510 \pm 32$ & 0.0 & 550 & n.d. & 0.0 & $507 \pm 30$ & 0.0 & $540.3 \pm 71.6$ & $945 \pm 51.3$ & $1306 \pm 45.5$ \\
\hline $\begin{array}{c}\quad \mathrm{H}_{2} \\
\text { consumption } \\
\left(\mathrm{mL} \cdot \mathrm{L}^{-1} \cdot \mathrm{d}^{-1}\right)\end{array}$ & 0.0 & $470 \pm 35$ & 0.0 & n.d. & n.d. & 0.0 & $507 \pm 30$ & 0.0 & $509.00 \pm 1.67$ & $854.9 \pm 3.48$ & $1168.41 \pm 4.98$ \\
\hline $\begin{array}{c}\mathrm{H}_{2} \\
\text { consumption } \\
(\%)\end{array}$ & 0.0 & 92.20 & 0.0 & n.d. & n.d. & 0.0 & 100.00 & 0.0 & 99.05 & 99.40 & 98.90 \\
\hline $\mathrm{pH}$ & $7.82 \pm 0.16$ & $8.49 \pm 0.04$ & n.d. & $8.6 \pm 0.0$ & $8.1 \pm 0$ & $7.49 \pm 0.17$ & $7.00-8.00$ & $8.57 \pm 0.19$ & $8.75 \pm 0.11$ & $8.88 \pm 0.09$ & $8.52 \pm 0.11$ \\
\hline $\begin{array}{c}\text { Organic } \\
\text { acids }\left(g \cdot \mathrm{L}^{-1}\right)\end{array}$ & $1.18 \pm 0.84$ & $0.38 \pm 0.07$ & 0.2 & 2.7 & 0.1 & n.d. & n.d. & n.d. & n.d. & n.d. & n.d. \\
\hline Acetate & n.d. & n.d. & n.d. & n.d. & n.d. & n.d. & n.d. & 0.00 & 0.06 & 0.04 & 0.04 \\
\hline Propionate & n.d. & n.d. & n.d. & n.d. & n.d. & n.d. & n.d. & 0.05 & 0.05 & 0.03 & 0.04 \\
\hline
\end{tabular}


Practically none of the most abundant 20 bacterial genera responded with elevated growth (Figure 6) to the daily $\mathrm{H}_{2} / \mathrm{CO}_{2}$ dosage into the headspace of the reactors although the microbes in the fed-batch reactors consumed the injected $\mathrm{H}_{2}$ completely within 16-24 h at all three $\mathrm{H}_{2}$ concentrations. The genus Ureibacillus did not follow the general trend, but its representation was severely decimated from $9.1 \%$ to $0.05 \%$ upon starvation (Table 1 ), therefore it became negligible and could not interfere with the life of the community. Moderate apparent inhibition by $\mathrm{H}_{2} / \mathrm{CO}_{2}$ was observed in the case of all bacterial genera (Figure 6). This was likely due to the fact that relative abundance values were used in the calculation of $\log 2 \mathrm{FC}$ and the predominance of the hydrogenotrophic genus Methanothermobacter, increased substantially in the $\mathrm{H}_{2} / \mathrm{CO}_{2}$-fed reactors.

Nevertheless, the presence of SAOBs among the most abundant 20 bacterial strains is noteworthy and the suspected SAOB-methanogen syntrophic contribution to the improvement of the P2M conversion demands further detailed study involving metatranscriptomics.

\section{Conclusions}

There are two "take home" messages from the studies reported in this paper. First, the fed-batch reactor configuration should be considered as an alternative to the widely used flow-through arrangement. The flow-through reactors are fine-tuned to minimize $\mathrm{H}_{2}$ loss in the effluent gas, therefore very low $\mathrm{H}_{2}$ injection rates are employed, which limits the attainable $\mathrm{CH}_{4}$ production rates. In addition, the infrastructure and delicate process control makes these approaches costly. Although a fed-batch P2M reactor works intermittently, the added benefits, i.e., high $\mathrm{H}_{2}$ loading rate, complete conversion of $\mathrm{H}_{2} / \mathrm{CO}_{2}$ to $\mathrm{CH}_{4}$ and low operation costs, can make this approach appealing for future scale-up development.

Second, we demonstrated that the genus Methanothermobacter is enriched as the sole predominant methanogenic taxon under the selection pressure of the P2M conditions. Consequently, a mixed microbial community from a thermophilic AD plant can simply be used as catalyst in the P2M reactors after a few days/weeks of enrichment period and maintenance of microbiologically pure conditions; addition of expensive complex medium and micro nutrients are not necessary. In so doing, the costs of the P2M operation at an industrial scale can be reduced substantially.

In future studies the economic analysis and the larger scale testing of the proposed novel P2M process are required.

Author Contributions: Conceptualization, K.L.K. and Z.B.; methodology, M.S. and R.W.; formal analysis and experimental investigation, M.S., G.M., and R.W.; resources, K.L.K. and Z.B.; data curation, R.W.; writing — original draft preparation, M.S. and K.L.K.; writing-review and editing, K.L.K. and Z.B.; supervision, G.R.; project administration, Z.B.; funding acquisition, K.L.K., G.R., R.W., G.M. All authors have read and agreed to the published version of the manuscript.

Funding: This work was supported by the European Regional Development Fund to projects INNOV-397-13/PALY-2020 (PI: G.R), 2020-1.1.2-PIACI KFI (PI: Z.B.), and by the bilateral scientific collaboration agreement 2019-2.1.13-TÉT_IN-2020-00016 (PI: K.L.K.). R.W. (PD132145), Z.B. (FK 123902) and G.M. (FK123899) received support from the National Research, Development and Innovation Office (NKFIH), Hungary. G.M. was also supported by the Lendület-Programme of the Hungarian Academy of Sciences (LP2020-5/2020).

Institutional Review Board Statement: Not applicable.

Informed Consent Statement: Not applicable.

Data Availability Statement: The raw sequence data obtained in this project have been uploaded on the NCBI SRA database under the project name: BioProject ID: PRJNA758802.

Conflicts of Interest: The authors declare no conflict of interest. The funders had no role in the design of the study; in the collection, analyses, or interpretation of data; in the writing of the manuscript, or in the decision to publish the results. 


\section{References}

1. REN21. Renewables 2020 Global Status Report. 2020. Available online: https:/ /www.ren21.net/reports/global-status-report/ ?gclid=CjwKCAjwoP6LBhBlEiwAvCcthM9n4BM6oHikcrY_nWbzC811LiRCEiGVVkKEgzPT2NcaGYXiUiOBkhoCLR4QAvD_ BwE (accessed on 1 November 2021).

2. Fawzy, S.; Osman, A.I.; Doran, J.; Rooney, D.W. Strategies for mitigation of climate change: A review. Environ. Chem. Lett. 2020, 18, 2069-2094. [CrossRef]

3. Østergaard, P.A. Comparing electricity, heat and biogas storages' impacts on renewable energy integration. Energy 2012, 37, 255-262. [CrossRef]

4. Lund, P.D.; Lindgren, J.; Mikkola, J.; Salpakari, J. Review of energy system flexibility measures to enable high levels of variable renewable electricity. Renew. Sustain. Energy Rev. 2015, 45, 785-807. [CrossRef]

5. Ketter, W.; Collins, J.; Saar-Tsechansky, M.; Marom, O. Information Systems for a Smart Electricity Grid. ACM Trans. Manag. Inf. Syst. 2018, 9, 1-22. [CrossRef]

6. Holladay, J.D.; Hu, J.; King, D.L.; Wang, Y. An overview of hydrogen production technologies. Catal. Today 2009, 139, 244-260. [CrossRef]

7. Thema, M.; Bauer, F.; Sterner, M. Power-to-Gas: Electrolysis and methanation status review. Renew. Sustain. Energy Rev. 2019, 112, 775-787. [CrossRef]

8. Sharma, S.; Ghoshal, S.K. Hydrogen the future transportation fuel: From production to applications. Renew. Sustain. Energy Rev. 2015, 43, 1151-1158. [CrossRef]

9. Herzog, A.; Tatsutani, M. A hydrogen future? An Economic and Environmental Assessment of Hydrogen Production Pathways. Nat. Resour. Def. Counc. 2005, 23.

10. Viswanathan, B. Hydrogen Storage. Energy Sources 2017, 185-212. [CrossRef]

11. Andrei, H.; Badea, C.A.; Andrei, P.; Spertino, F. Energetic-Environmental-Economic Feasibility and Impact. Energies 2020, 14, 100. [CrossRef]

12. Campana, P.E.; Mainardis, M.; Moretti, A.; Cottes, M. 100\% renewable wastewater treatment plants: Techno-economic assessment using a modelling and optimization approach. Energy Convers. Manag. 2021, 239, 114214. [CrossRef]

13. Luo, G.; Johansson, S.; Boe, K.; Xie, L.; Zhou, Q.; Angelidaki, I. Simultaneous hydrogen utilization and in situ biogas upgrading in an anaerobic reactor. Biotechnol. Bioeng. 2012, 109, 1088-1094. [CrossRef] [PubMed]

14. Global Methane Initiative. Global Methane Emissions and Mitigation Opportunities; Global Methane Initiative: Washington, DC, USA, 2010; Volume 2020, pp. 1-4. Available online: https:/ / www.globalmethane.org/documents/gmi-mitigation-factsheet.pdf (accessed on 1 November 2021).

15. Angelidaki, I.; Treu, L.; Tsapekos, P.; Luo, G.; Campanaro, S.; Wenzel, H.; Kougias, P.G. Biogas upgrading and utilization: Current status and perspectives. Biotechnol. Adv. 2018, 36, 452-466. [CrossRef]

16. Piechota, G. Biogas/Biomethane Quality and Requirements for Combined Heat and Power (CHP) Units/Gas Grids with a Special Focus on Siloxanes-a Short Review. Sustain. Chem. Eng. 2022, 3, 1-10.

17. Piechota, G. Multi-step biogas quality improving by adsorptive packed column system as application to biomethane upgrading. J. Environ. Chem. Eng. 2021, 9, 105944. [CrossRef]

18. Angelidaki, I.; Karakashev, D.; Batstone, D.J.; Plugge, C.M.; Stams, A.J.M. Biomethanation and Its Potential, 1st ed.; Elsevier Inc.: Amsterdam, The Netherlands, 2011. [CrossRef]

19. Götz, M.; Lefebvre, J.; Mörs, F.; Koch, A.M.; Graf, F.; Bajohr, S.; Reimert, R.; Kolb, T. Renewable Power-to-Gas: A technological and economic review. Renew. Energy 2016, 85, 1371-1390. [CrossRef]

20. Rafrafi, Y.; Laguillaumie, L.; Dumas, C. Biological Methanation of H2 and CO2 with Mixed Cultures: Current Advances, Hurdles and Challenges. Waste Biomass Valorization 2020, 12, 5259-5282. [CrossRef]

21. Wahid, R.; Horn, S.J. Impact of operational conditions on methane yield and microbial community composition during biological methanation in in situ and hybrid reactor systems. Biotechnol. Biofuels 2021, 14, 170. [CrossRef]

22. Adnan, A.I.; Ong, M.Y.; Nomanbhay, S.; Chew, K.W. Technologies for Biogas Upgrading to Biomethane: A Review. Bioengineering 2019, 6, 92. [CrossRef] [PubMed]

23. Rusmanis, D.; O'Shea, R.; Wall, D.M.; Murphy, J.D. Biological hydrogen methanation systems-an overview of design and efficiency. Bioengineered 2019, 10, 604-634. [CrossRef]

24. Rittmann, S.; Seifert, A.; Herwig, C. Essential prerequisites for successful bioprocess development of biological CH4 production from CO2 and H2. Crit. Rev. Biotechnol. 2015, 35, 141-151. [CrossRef] [PubMed]

25. Peillex, J.P.; Fardeau, M.L.; Boussand, R.; Navarro, J.M.; Belaich, J.P. Growth of Methanococcus thermolithotrophicus in batch and continuous culture on $\mathrm{H} 2$ and CO2: Influence of agitation. Appl. Microbiol. Biotechnol. 1988, 29, 560-564. [CrossRef]

26. de Poorter, L.M.I.; Geerts, W.J.; Keltjens, J.T. Coupling of Methanothermobacter thermautotrophicus methane formation and growth in fed-batch and continuous cultures under different $\mathrm{H} 2$ gassing regimens. Appl. Environ. Microbiol. 2007, 73, 740-749. [CrossRef]

27. Strevett, K.A.; Vieth, R.F.; Grasso, D. Chemo-autotrophic biogas purification for methane enrichment: Mechanism and kinetics. Chem. Eng. J. Biochem. Eng. J. 1995, 58, 71-79. [CrossRef]

28. Szuhaj, M.; Ács, N.; Tengölics, R.; Bodor, A.; Rákhely, G.; Kovács, K.L.; Bagi, Z. Conversion of H2and CO2to CH4and acetate in fed-batch biogas reactors by mixed biogas community: A novel route for the power-to-gas concept. Biotechnol. Biofuels 2016, 9, 102. [CrossRef] 
29. Bassani, I.; Kougias, P.G.; Treu, L.; Angelidaki, I. Biogas Upgrading via Hydrogenotrophic Methanogenesis in Two-Stage Continuous Stirred Tank Reactors at Mesophilic and Thermophilic Conditions. Environ. Sci. Technol. 2015, 49, 12585-12593. [CrossRef]

30. Bassani, I.; Kougias, P.G.; Treu, L.; Porté, H.; Campanaro, S.; Angelidaki, I. Optimization of hydrogen dispersion in thermophilic up-flow reactors for ex situ biogas upgrading. Bioresour. Technol. 2017, 234, 310-319. [CrossRef] [PubMed]

31. Agneessens, L.M.; Ottosen, L.D.M.; Voigt, N.V.; Nielsen, J.L.; de Jonge, N.; Fischer, C.H.; Kofoed, M.V.W. In-situ biogas upgrading with pulse H2additions: The relevance of methanogen adaption and inorganic carbon level. Bioresour. Technol. 2017, 233, 256-263. [CrossRef]

32. Luo, G.; Angelidaki, I. Integrated biogas upgrading and hydrogen utilization in an anaerobic reactor containing enriched hydrogenotrophic methanogenic culture. Biotechnol. Bioeng. 2012, 109, 2729-2736. [CrossRef]

33. Strübing, D.; Huber, B.; Lebuhn, M.; Drewes, J.E. High performance biological methanation in thermophilic anaerobic trickle bed reactors. Bioresour. Technol. 2017, 245, 1176-1183. [CrossRef] [PubMed]

34. Rachbauer, L.; Beyer, R.; Bochmann, G.; Fuchs, W. Characteristics of adapted hydrogenotrophic community during biomethanation. Sci. Total Environ. 2017, 595, 912-919. [CrossRef] [PubMed]

35. Ács, N.; Szuhaj, M.; Wirth, R.; Bagi, Z.; Maróti, G.; Rákhely, G.; Kovács, K.L. Microbial Community Rearrangements in Power-to-Biomethane Reactors Employing Mesophilic Biogas Digestate. Front. Energy Res. 2019, 7, 132. [CrossRef]

36. Bassani, I.; Kougias, P.G.; Angelidaki, I. In-situ biogas upgrading in thermophilic granular UASB reactor: Key factors affecting the hydrogen mass transfer rate. Bioresour. Technol. 2016, 221, 485-491. [CrossRef] [PubMed]

37. Afgan, E.; Baker, D.; van den Beek, M.; Blankenberg, D.; Bouvier, D.; Čech, M.; Chilton, J.; Clements, D.; Coraor, N.; Eberhard, C.; et al. The Galaxy platform for accessible, reproducible and collaborative biomedical analyses: 2016 update. Nucleic Acids Res. 2016, 44, W3-W10. [CrossRef]

38. Schmieder, R.; Edwards, R. Quality control and preprocessing of metagenomic datasets. Bioinformatics 2011, 27, 863-864. [CrossRef]

39. Menzel, P.; Ng, K.L.; Krogh, A. Fast and sensitive taxonomic classification for metagenomics with Kaiju. Nat. Commun. 2016 7, 11257. [CrossRef]

40. Mende, D.R.; Letunic, I.; Huerta-Cepas, J.; Li, S.S.; Forslund, K.; Sunagawa, S.; Bork, P. ProGenomes: A resource for consistent functional and taxonomic annotations of prokaryotic genomes. Nucleic Acids Res. 2017, 45, D529-D534. [CrossRef]

41. Letunic, I.; Bork, P. Interactive Tree of Life (iTOL) v4: Recent updates and new developments. Nucleic Acids Res. 2019, 47, 256-259. [CrossRef]

42. Siriwongrungson, V.; Zeng, R.J.; Angelidaki, I. Homoacetogenesis as the alternative pathway for H2 sink during thermophilic anaerobic degradation of butyrate under suppressed methanogenesis. Water Res. 2007, 41, 4204-4210. [CrossRef]

43. Bouanane-Darenfed, A.; Hania, W.B.; Cayol, J.L.; Ollivier, B.; Fardeau, M.L. Reclassification of acetomicrobium faecale as caldicoprobacter faecalis comb. Nov. Int. J. Syst. Evol. Microbiol. 2015, 65, 3286-3288. [CrossRef]

44. Avdiyuk, K.V. Keratinolytic Enzymes: Producers, Physical and Chemical Properties. Application for Biotechnology. Biotechnol. Acta 2019, 12, 27-45. [CrossRef]

45. Fortina, M.G.; Pukall, R.; Schumann, P.; Mora, D.; Parini, C.; Manachini, P.L.; Stackebrandt, E. Ureibacillus gen. nov., a new genus to accommodate Bacillus thermosphaericus (Andersson et al. 1995), emendation of Ureibacillus thermosphaericus and description of Ureibacillus terrenus sp. nov. Int. J. Syst. Evol. Microbiol. 2001, 51, 447-455. [CrossRef]

46. Weon, H.Y.; Lee, S.Y.; Kim, B.Y.; Noh, H.J.; Schumann, P.; Kim, J.S.; Kwon, S.W. Ureibacillus composti sp. nov. and Ureibacillus thermophilus sp. nov., isolated from livestock-manure composts. Int. J. Syst. Evol. Microbiol. 2007, 57, 2908-2911. [CrossRef]

47. Maus, I.; Koeck, D.E.; Cibis, K.G.; Hahnke, S.; Kim, Y.S.; Langer, T.; Kreubel, J.; Erhard, M.; Bremges, A.; Off, S.; et al. Unraveling the microbiome of a thermophilic biogas plant by metagenome and metatranscriptome analysis complemented by characterization of bacterial and archaeal isolates. Biotechnol. Biofuels 2016, 9, 1-28. [CrossRef]

48. Shiratori, H.; Ohiwa, H.; Ikeno, H.; Ayame, S.; Kataoka, N.; Miya, A.; Beppu, T.; Ueda, K. Lutispora thermophila gen. nov., sp. nov., a thermophilic, spore-forming bacterium isolated from a thermophilic methanogenic bioreactor digesting municipal solid wastes. Int. J. Syst. Evol. Microbiol. 2008, 58, 964-969. [CrossRef]

49. Logroño, W.; Popp, D.; Kleinsteuber, S.; Sträuber, H.; Harms, H.; Nikolausz, M. Microbial resource management for ex situ biomethanation of hydrogen at alkaline ph. Microorganisms 2020, 8, 614. [CrossRef] [PubMed]

50. Wasserfallen, A.; Nölling, J.; Pfister, P.; Reeve, J.; de Macario, E.C. Phylogenetic analysis of 18 thermophilic Methanobacterium isolates supports the proposals to create a new genus, Methanothermobacter gen. nov., and to reclassify several isolates in three species, Methanothermobacter thermautotrophicus comb. nov., Methano. Int. J. Syst. Evol. Microbiol. 2000, 50, 43-53. [CrossRef] [PubMed]

51. Cao, Y.; Wang, L.; Qian, Y.; Xu, Y.; Wu, H.; Zhang, J.; Huang, H.; Chang, Z. Contributions of thermotolerant bacteria to organic matter degradation under a hyperthermophilic pretreatment process during chicken manure composting. BioResources 2019, 14, 6747-6766. [CrossRef]

52. Gorliczay, E.; Boczonádi, I.; Kiss, N.É.; Tóth, F.A.; Pabar, S.A.; Biró, B.; Kovács, L.R.; Tamás, J. Microbiological effectivity evaluation of new poultry farming organic waste recycling. Agric 2021, 11, 683. [CrossRef]

53. Vaz-Moreira, I.; Faria, C.; Nobre, M.F.; Schumann, P.; Nunes, O.C.; Manaia, C.M. Paenibacillus humicus sp. nov., isolated from poultry litter compost. Int. J. Syst. Evol. Microbiol. 2007, 57, 2267-2271. [CrossRef]

54. McInerney, M.J.; Bryant, M.P.; Hespell, R.B.; Costerton, J.W. Syntrophomonas wolfei gen. nov. sp. nov., an anaerobic, syntrophic, fatty acid-oxidizing bacterium. Appl. Environ. Microbiol. 1981, 41, 1029-1039. [CrossRef] 
55. Westerholm, M.; Roos, S.; Schnürer, A. Syntrophaceticus schinkiigen. nov., sp. nov., an anaerobic, syntrophic acetate-oxidizing bacterium isolated from a mesophilic anaerobic filter. FEMS Microbiol. Lett. 2010, 309, 100-104. [CrossRef]

56. United Nations. Adoption of the Paris Agreement, Proposal by the President, Draft decision. In Proceedings of the Twenty-First Session of the Conference of the Parties (COP 21), Paris, France, 11 December 2015; Volume 32, p. 21932. Available online: http:/ / unfccc.int/resource/docs/2015/cop21/eng/109r01.pdf (accessed on 1 November 2021).

57. Csedő, Z.; Zavarkó, M.; Vaszkun, B.; Koczkás, S. Hydrogen Economy Development Opportunities by Inter-Organizational Digital Knowledge Networks. Sustainability 2021, 13, 9194. [CrossRef]

58. Kakuk, B.; Wirth, R.; Maróti, G.; Szuhaj, M.; Rakhely, G.; Laczi, K.; Kovács, K.L.; Bagi, Z. Early response of methanogenic archaea to $\mathrm{H} 2$ as evaluated by metagenomics and metatranscriptomics. Microb. Cell Fact. 2021, 20, 127. [CrossRef] [PubMed]

59. Kleinsteuber, S. Metagenomics of Methanogenic Communities in Anaerobic Digesters. In Biogenesis of Hydrocarbons Handbook of Hydrocarbon and Lipid Microbiology; Springer: Cham, Switzerland, 2019; pp. 337-359. [CrossRef]

60. Corbellini, V.; Kougias, P.G.; Treu, L.; Bassani, I.; Malpei, F.; Angelidaki, I. Hybrid biogas upgrading in a two-stage thermophilic reactor. Energy Convers. Manag. 2018, 168, 1-10. [CrossRef]

61. Mulat, D.G.; Mosbæk, F.; Ward, A.J.; Polag, D.; Greule, M.; Keppler, F.; Nielsen, J.L.; Feilberg, A. Exogenous addition of H2for an in situ biogas upgrading through biological reduction of carbon dioxide into methane. Waste Manag. 2017, 68, 146-156. [CrossRef] [PubMed]

62. Bagi, Z.; Ács, N.; Böjti, T.; Kakuk, B.; Rákhely, G.; Strang, O.; Szuhaj, M.; Wirth, R.; Kovács, K.L. Biomethane: The energy storage, platform chemical and greenhouse gas mitigation target. Anaerobe 2017, 46, 13-22. [CrossRef]

63. Agneessens, L.M.; Ottosen, L.D.M.; Andersen, M.; Olesen, C.B.; Feilberg, A.; Kofoed, M.V.W. Parameters affecting acetate concentrations during in-situ biological hydrogen methanation. Bioresour. Technol. 2018, 258, 33-40. [CrossRef]

64. Waldron, C.R.; Becker-Vallone, C.A.; Eveleigh, D.E. Isolation and characterization of a cellulolytic actinomycete Microbispora bispora. Appl. Microbiol. Biotechnol. 1986, 24, 477-486. [CrossRef]

65. Li, Y.; Chen, F.; Dong, K.; Wang, G. Actinotalea ferrariae sp. nov., isolated from an iron mine, and emended description of the genus Actinotalea. Int. J. Syst. Evol. Microbiol. 2013, 63, 3398-3403. [CrossRef]

66. Stackebrandt, E.; Kandler, O. Taxonomy of the genus Cellulomonas, based on phenotypic characters and deoxyribonucleic acid-deoxyribonucleic acid homology, and proposal of seven neotype strains. Int. J. Syst. Bacteriol. 1979, 29, 273-282. [CrossRef]

67. Kushkevych, I.; Cejnar, J.; Vítězová, M.; Vítěz, T.; Dordević, D.; Bomble, Y. Occurrence of thermophilic microorganisms in different full scale biogas plants. Int. J. Mol. Sci. 2020, 21, 283. [CrossRef]

68. Nouioui, I.; Carro, L.; García-López, M.; Meier-Kolthoff, J.P.; Woyke, T.; Kyrpides, N.C.; Pukall, R.; Klenk, H.P.; Goodfellow, M.; Göker, M. Genome-based taxonomic classification of the phylum actinobacteria. Front. Microbiol. 2018, 9, 1-119. [CrossRef]

69. Hattori, S.; Kamagata, Y.; Hanada, S. A Strictly Anaerobic, Thermophilic, Syntrophic Acetate-Oxidizing Bacterium. Int. J. Syst. Evol. Microbiol. 2000, 50, 1601-1609. [CrossRef] [PubMed]

70. Sattar, A.; Zakaria, Z.; Abu, J.; Aziz, S.A.; Rojas-Ponce, G. Isolation of Mycobacterium avium and other nontuberculous mycobacteria in chickens and captive birds in peninsular Malaysia. BMC Vet. Res. 2021, 17, 13. [CrossRef] [PubMed]

71. Dyksma, S.; Jansen, L.; Gallert, C. Syntrophic acetate oxidation replaces acetoclastic methanogenesis during thermophilic digestion of biowaste. Microbiome 2020, 8, 105. [CrossRef] [PubMed]

72. FitzGerald, J.A.; Allen, E.; Wall, D.M.; Jackson, S.A.; Murphy, J.D.; Dobson, A.D.W. Methanosarcina play an important role in anaerobic co-digestion of the seaweed ulva lactuca: Taxonomy and predicted metabolism of functional microbial communities. PLoS ONE 2015, 10, e0142603. [CrossRef] [PubMed]

73. Silva, T.C.D.; Isha, A.; Chandra, R.; Vijay, V.K.; Subbarao, P.M.V.; Kumar, R.; Chaudhary, V.P.; Singh, H.; Khan, A.A.; Tyagi, V.K.; et al. Enhancing methane production in anaerobic digestion through hydrogen assisted pathways-A state-of-the-art review. Renew. Sustain. Energy Rev. 2021, 151, 111536. [CrossRef] 